San Jose State University

SJSU ScholarWorks

Master's Theses

Master's Theses and Graduate Research

1990

\title{
The response of the Australian press to Australia's change in foreign policy toward Indonesia between 1963 and 1970
}

Marisa Whalen Gaines
San Jose State University

Follow this and additional works at: https://scholarworks.sjsu.edu/etd_theses

\section{Recommended Citation}

Whalen Gaines, Marisa, "The response of the Australian press to Australia's change in foreign policy toward Indonesia between 1963 and 1970" (1990). Master's Theses. 46.

DOI: https://doi.org/10.31979/etd.mjuy-f9bb

https://scholarworks.sjsu.edu/etd_theses/46

This Thesis is brought to you for free and open access by the Master's Theses and Graduate Research at SJSU ScholarWorks. It has been accepted for inclusion in Master's Theses by an authorized administrator of SJSU ScholarWorks. For more information, please contact scholarworks@sjsu.edu. 


\section{INFORMATION TO USERS}

The most advanced technology has been used to photograph and reproduce this manuscript from the microfilm master. UMI films the text directly from the original or copy submitted. Thus, some thesis and dissertation copies are in typewriter face, while others may be from any type of computer printer.

The quality of this reproduction is dependent upon the quality of the copy submitted. Broken or indistinct print, colored or poor quality illustrations and photographs, print bleedthrough, substandard margins, and improper alignment can adversely affect reproduction.

In the unlikely event that the author did not send UMI a complete manuscript and there are missing pages, these will be noted. Also, if unauthorized copyright material had to be removed, a note will indicate the deletion.

Oversize materials (e.g., maps, drawings, charts) are reproduced by sectioning the original, beginning at the upper left-hand corner and continuing from left to right in equal sections with small overlaps. Each original is also photographed in one exposure and is included in reduced form at the back of the book.

Photographs included in the original manuscript have been reproduced xerographically in this copy. Higher quality 6" $x$ 9" black and white photographic prints are available for any photographs or illustrations appearing in this copy for an additional charge. Contact UMI directly to order.

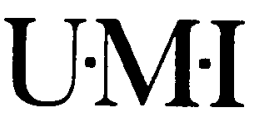

University Microfilms International

A Bell \& Howell Information Company

300 North Zeeb Road. Ann Arbor. MI 48106-1346 USA

313/761-4700 800/521-0600 
The response of the Australian press to Australia's change in foreign policy toward Indonesia between 1963 and 1970

Gaines, Marisa Whalen, M.S.

San Jose State University, 1990 


\title{
THE RESPONSE OF THE AUSTRALIAN PRESS TO AUSTRALIA'S CHANGE IN
} FOREIGN POLICY TOWARD INDONESIA BETWEEN 1963 AND 1970

\author{
A Thesis \\ Presented to \\ The Faculty of the Department of Journalism \\ and Mass Communications \\ San Jose State University
}

In Partial Fulfillment

of the Requirements for the Degree

Master of Science

by

Marisa Whalen Gaines

December 1990 
APPROVED FOR THE DEPARTMENT OF JOURNALISM AND MASS COMMUNICATIONS
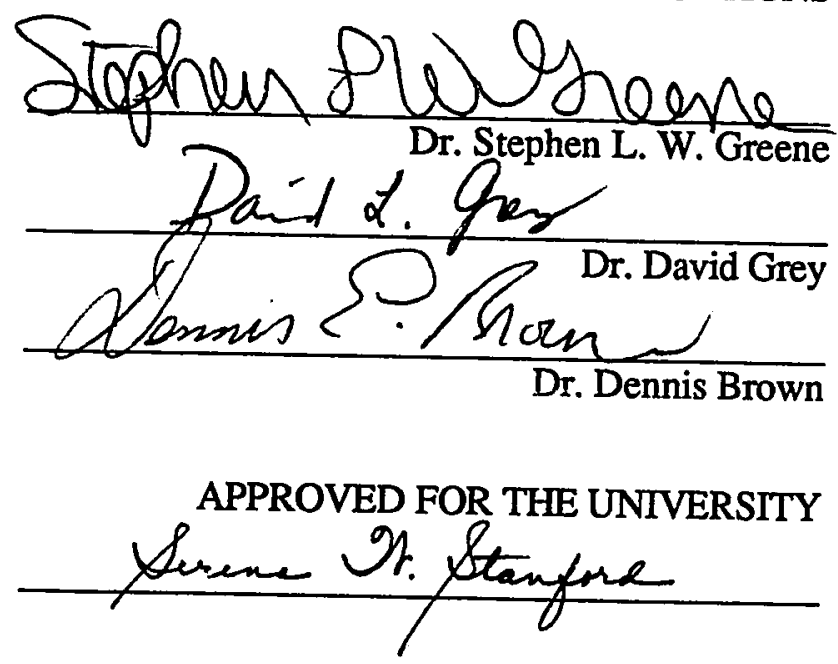


\begin{abstract}
THE RESPONSE OF THE AUSTRALIAN PRESS TO THE AUSTRALIAN GOVERNMENT'S CHANGE IN FOREIGN POLICY TOWARD INDONESIA 19631970
\end{abstract}

by Marisa Whalen Gaines

This thesis addresses the topic of the response of the Australian press to the Australian government's change in foreign policy toward Indonesia between 1963 and 1970. It examines the reasons why the government changed its foreign policy toward Indonesia and why the press so closely reflected this change.

Research on this subject reveals that both the government and the press shared a belief in the domino theory and considered Australia to be particularly vulnerable to communist aggression. In September 1965, a coup and counter-coup in Indonesia began the fall of President Sukarno, and the subsequent rise of General Suharto. Suharto quickly made peace with Australia's ally Malaysia and restored internal order by completely eradicating Indonesia's communist party, the Partai Komunis Indonesia (PKI). Within nine months of these policy changes by Suharto, the Australian government, championed by editorial opinion in the press, re-established diplomatic ties with Indonesia. 


\section{TABLE OF CONTENTS}

\section{Chapter}

1. Introduction

2. Literature Review 5

3. A Review of Australian-IndonesianRelations 12

4. The Australian Government's Foreign Policy Toward Indonesia 1963 to 1965

5. The Tone of the Australian Press Toward Indonesia 1963 to 1965

6. The Australian Government's Foreign Policy Toward Indonesia 1965 to 1970

7. How the Australian Government Manifested Its Change in Foreign Policy Toward Indonesia

8. The Tone of the Australian Press Toward Indonesia 1965 to $1970 \quad 37$

9. Conclusion 


\section{CHAPTER 1}

\section{Introduction}

Australia is a westem culture located near Southeast Asia. Although Australia has always been conscious of its proximity to the Third World countries of Asia, the cultural, political, and economic differences between the two land masses encouraged, at least on Australia's part, an isolationism similar to that of the United States toward Europe prior to World War ll. Not until Britain began planning to withdraw from east of Suez did she feel the need for regional alliances. Nothing before had been as successful at making Australians confront the old adage "geography is destiny."

Consequently, during the 1960 s, Australia, for the first time in its history, began devising its own foreign policy. As China was.seen as the main threat to national security, the domino theory became the major force shaping foreign policy (during this time period both Australia and the United States believed that a monolithic communism would spread out from China and Russia felling, like lined-up dominos, those countries in its path). Looking around for regional allies, Austrilia's closest neighbor, Indonesia, with a population of 100 million in 1960 and with great economic potential, seemed a logical choice.

Confounding long-term diplomatic goals, however, were a number of crises, namely: the conflict over Indonesia's right to Western New Guinea, lack of an agreed upon border between Indonesia's Irian Jaya and Australian controlled Papua-New Guinea, and Indonesia's "confrontation" with Australia's ally, Malaysia. Fear of communist China was the main reason Australia was so alarmed by Indonesia's "confrontation" with Malaysia. Australian foreign policy makers were convinced that if President Sukamo were 
allowed to dismember the newly forming Federation of Malay States, then the "Yellow Peril" would stream down the Malay peninsula and soon be swarming onto Australia's vulnerable northern shore; in 1963 Australia had a population of 10 million that was mainly concentrated in cities of 100,000 or more in the southern regions of the continent. In . addition, Sukarno had already forged alliances with both the Soviet Union and Communist China and Indonesia possessed, with Sukarno's apparent complicity, one of the largest communist parties in the world, the Partai Komunis Indonesia (PKI).

Indonesia's opposition to Malaysia, however, lasted only as long as Sukarno was in power. When he was ousted in 1965, Indonesia's confrontation with Malaysia ended; the Australian government's foreign policy toward Indonesia changed accordingly.

Australia's relations with Indonesia started auspiciously in 1949 when she supported Indonesia's declaration of independence from the Netherlands. Sukarno, who had been one of the leaders of the revolution, had held power since 1945.

In 1959 Sukamo declared that Indonesia's liberal democratic form of government had failed. In the same year, the People's Consultative Congress, the supreme authority of government, gave him the power to govem by decree. His power became so great that in 1961 the Congress declared him President for life.

Sukarno took control of a country that commands one of the most strategic locations on the globe. Indonesia lies between the continents of Australia and Asia and straddles the major sea lanes connecting Western Asia with China and the Pacific. The Republic of Indonesia covers an area of 788,421 square miles and includes the major islands of Sumatra, Java, Sulawesi, Halmahera, Seram, Flores and Timor, Kalimantan (Southern Borneo), Irian Jaya (Western New Guinea), and 13,000 lesser islands in the Java, Banda, and Arafura seas. The eastern half of Timor (formerly Portuguese East Timor, now Loro Sae) was occupied by Indonesia in 1975 and made a province in 1976. 
Indonesia has the fifth largest population in the world just behind China, the Soviet Union, U.S.A., and Brazil.

Indonesia's geographical location, as well as vast reserves of tin and nickel ores, copper, manganese, coal and huge supplies of oil and natural gas, have made it an area of international political and military significance since colonial times. By the time Holland had colonized Indonesia in 1619, Britain, Portugual, and France had all jockeyed for control of these "spice islands." Consequently, by the time Indonesia became independent in 1949, it had been under colonial domination for over 350 years. Australia supported Indonesia through its independence movement and up to the time when the government perceived Sukarno's foreign policies as jeopardizing Australia's security.

Several studies have found that a country's foreign policy interests and that .country's press coverage are positively related. ${ }^{1}$ The portrayal of foreign countries in the U.S. media, for example, is influenced by the changing relations between the United States government and those countries. Other nations are portrayed in a positive light in the U.S. press when their governments maintain harmonious relations with the United States.

This study will determine if the Australian press follows this model of newspaper coverage in which, although the government exerts no overt influence over news content, the press tends to align its editorial policy with foreign policy, especially during crises.

The period of this study, 1963 to 1970, incorporates the years before and after the ouster of Sukamo. It will demonstrate how the Australian press reflected the government's foreign policy over time.

1 H. Sahin, "Turkish Poiitics in the New Yost Times," Loumalism Onerterly 50 (Winter 1973): 687. M.D. Lynch \& A. Effendi, "The Editorial Treatment of India in the New York Times," Iournglism Ounrterly 41 (Summer 1964): 431.

W.A. Dorman \& M. Farhang, The U.S. Press and Irmi Foreien Poling and the Jouralism of Deference. (Rerkeley: University of California Press, 1987), 64. 
This descriptive study looked at every edition of Australia's two elite newspapers, the Melbourne Age and the Sydney Morning Herald, from January 1963 to December 1970.

Each reference to Indonesia was recorded and dated so that correlations could be made between tone and time period.

References to Indonesia in the government's Department of Foreign Affairs publication Australia in Facts and Figures were also recorded and dated so that comparisons could be made between the government's stated foreign policy toward Indonesia during this time period and the tone of the selected newspapers. 


\section{CHAPTER 2}

\section{Literature Review}

According to H.C. Mott, former senior spokesman for Australia's Department of Foreign Affairs, Australian newspapers sometimes reveal a lack of understanding of the problems of the developing countries. Often they seem to regard those countries solely with an Australian perspective--if they don't accept the same values as we do, something must be wrong. ${ }^{1}$ Researchers have echoed this sentiment, finding that mass media ethnocentrism is pervasive throughout the international press. As Hans Morgenthau suggests, "all the news that is fit to print" means one thing for The New York Times, another thing for Pravda, and yet another for the Hindustani Times. ${ }^{2}$

According to Gans, ethnocentrism comes through most explicitly in foreign news which judges other countries by the extent to which they live up to or imitate their own country's practices and values. ${ }^{3}$ W.A. Dorman and Mansour Farhang in their study of the United States press and Iran concluded that between 1951 and 1978 the mainstream American press exercised little independent judgment in covering Iranian life or examining. U.S. policy. "Journalism performance toward Iran was seriously flawed by the subtle interplay of ideology, ethnocentrism, dubious professional practice, and economic force."4

Similarly in Australia, Mott contends that there is a trend in the Australian press community to look for a domestic angle in any important story, to accentuate any such

\footnotetext{
1 H.C. Mott "The Media and Foreign Policy," Ausrralian Foreien Affairs Recond (Department of Foreign Affairs, Australian Govt. Publishing Service, N.S.W., Australie, 1976), 546.

2 M.D. Lynch \& A. Effendi, "The Editorial Treatment of India in the New York Times," Joumalism Quarterly 41 (Summer 1964): 431.

3 H.J. Gans, Deciding What's News (New York: Vintage Books, 1979), 78.

4 W.A Dorman \& M. Fartang. The U.S. Press and Irani- Foreign Policy and the Joumalism of Deference (Berkeley: University of California Press, 1987), 64.
} 
angle where it does exist and perhaps to develop one where it does not, thus distorting the story itself. 5

For example, in his study of "The United States Press Down Under," Budic discovered that there was a correlation between the country's economic interests and the way its newspapers reflected economic activity. For example, there was a 63 per cent margin of favorability toward the United States in the four Australian newspapers studied, and only a 12 per cent margin in the four New Zealand publications. Budd felt that these figures reflected the deeper trade commitment of Australia to the United States. In addition, during the period of this investigation, Australian industrialists were attempting to attract United States business to Australia, while New Zealand was having its troubles with a beef shipment rejected by the United States because it was believed to be contaminated by insect spray. 6

A number of studies have found that the United States foreign policy interests and United States press coverage of other countries are positively related, that is, the portrayal of foreign countries in the U.S. media is influenced by the changing relations between the United States and those countries. Other nations are portrayed in a positive light in the U.S. press when their governments maintain harmonious relations with the Cinitad States.

Sahin's content analysis of the New York Times in 1973 concluded that its coverage of a particular foreign country tends to parallel the foreign policy of the United States towards that country. When there is a friendly relationship with a country, the news coverage about that country tends to be favorable, and when a drastic change occurs in the relationship with the country, its news coverage changes accordingly.

The purpose of the study was to find out whether news reporting of the New York Times changed in response to shifts in Turkish-American political relations. Sahin chose

5 Moth, 549

6 R.W. Budd, "U.S. news in the press Down Under," Public Opinion Ounrterly 28 (Winter 1964); 41. 
two periods that were in clear contrast to each other in terms of Turkish-American relations. The first period, 1951-54 when Turkish Democratic President Celal Bayer and Prime Minister Adnan Menderes were in power, is considered the peak of Turkish-American political amity. The second period, 1965-68, has been labeled as the anti-American period in Turkish history. Some of the reasons for this were Turkish disappointment over the U.S. policies concerning Cyprus, dissatisfactions with U.S. economic aid, and alleged CIA attempts to intervene in Tukkish domestic affairs.

During the first period, the Turkish government received a large amount of U.S. military aid, furnished military bases to the United States and was admitted to the North Atlantic Treaty Organization, as a result of a strong American endorsement. 7

Sahin used an evaluative assertion analysis, a technique of content analysis which seeks to extract from news articles a significant concept. Assertions about Turkish political figures, and systems such as presidents, prime ministers, and political parties were placed on a +3 to -3 scale (very favorable to very unfavorable). During the 1951-54 period, the Menderes government received a positive 2.19 score, as compared to a negative 2.8 for the Inonu government in the years of increasing discord.

On the basis of the findings, Sahin concluded that the New York Times evaluative assessment of foreign political figures and institutions changes in response to shifts in American foreign policy.8

Similar findings were obtained in a study of the editorial treatment of India in the New York Times by Lynch and Effendi. They examined the period between January, 1950, through December, 1962. This period represented three different stages of Indian political developments. These were the 1950 to 1953 period, when India first became actively involved in intemational affairs; the second was the 1954 to 1958 period, when

\footnotetext{
7 H. Sahin, "Turkish Politics in the New York Times," Loumalism Ounterly 50 (Winter 1973): 687.

8 Sahin, 688.
} 
India seemed to lean toward the Communist bloc countries; and, third, the 1959 to 1962 period, when India leaned towand the Western nations--the United States and Western Europe.9

Evaluative assertion analysis was also used in this study, and five assertions were utilized to characterize India: nationalism; relations with the West; relations with the Communist bloc; relations with Asian countries; and leadership. The higher the mean score, the more ravorable the assertion. Findings also indicate that the amount of coverage of other countries also tends to increase when America's political and economic interests are at stake in those countries.

In each of the time periods mentioned (from 1950 to 1962), the mean score for assertions involving India's relations with the Communist bloc was less favorable than those involving India's relations with the West, nationlism, and leadership. During the second period (1954 to 1958) when India was close to the Communist bloc, the mean score for five categories combined was 4.07 , as compared with 4.46 for the third period (1959 to 1962), when India was pro-Western, especially towards the United States. Lynch and Effendi concluded that the increasingly favorable editorial treatment during the third period, suggesting improved relations between the United States and India, was due "to the Chinese Communist invasion of India, the resignation of Krishna Menon and other events." 10

Martin Kriesberg also utilized the New York Times in a content analysis of the period 1917 to 1946. He examined parallels between the New York Times coverage of the Soviet Union and America's foreign policy interests. ${ }^{11}$

When events in Russia were described in terms contrary to American values, the New York Times reported those events negatively. For example, according to American

9 Lynch \& Effendi, 430.

10 Ibid., 432.

11 M. Kriesberg, "Soviet News in the New York Times," Public Opinon Ougrterly 10 (Winter 1946): 560. 
democratic tradition, a government should be popular and representative of its own people. When the Bolshevik government was described as not representative of the Russian people, the government and its leaders were reported unfavorably. Stories of widespread opposition to the Bolshevik leaders were circulated in the Times. During World War ll when the Russians and the United States were fighting against the same enemy, the image of the Soviet government that emerged in the Times was markedly different. They were depicted as interprising and forceful; the Russian people were resolute fighters, faithfully defending their homeland.

A government's foreign policies, especially if not a major power, are likeiy to be highly influenced by next door giant neighbors, and their mass media tend to give them a high degree of attention. This is supported in a study by Liu and Gunaratne who compared the foreign news coverage of the two elite newspapers in Ceylon and Taiwan. They found that the Central Daily News, the Chinese language party newspaper of the Kuomintang reflected the anti-Communist approach of the Nationalist Chinese government in its foreign news presentation. This was seen in the relatively little attention paid to communist countries with the exception of mainland China. Liu and Gunaratne feit that Taiwan's proximity to mainland China and the adverse political relations between the two countries were probable reasons for this exception. The fact that much attention was paid to the United States and Japan, demonstrated Taiwan's close relationship to those two countries. ${ }^{12}$

The Ceylon Daily News, a pro-Western newspaper, did not always reflect the political philosophy of the government. But India, Ceylon's giant neighbor, was given primary attention followed by the United States (16.4 and 15.1 per cent of foreign news, respectively).

12 H.C. Liu \& S.A. Gunarame, "Foreign News in Two Asian Dailies," Gazente 18 (January 1972): 39. 
Similar findings were reported in two separate studies by Merrill ${ }^{13}$ and Hart. 14 Merrill found that 37 percent of all foreign news in ten Mexican dailies was on the United States, while Hart found that the foreign news content of the Canadian dailies he studied contained 51-60 percent news on the United States.

Government and media preocccupation with the proximate land mass was typical of Australia, especially during the Cold War years. "It is only sheer good luck that our relations with our Southeast Asian neighbors developed fairly smoothly during the earlier post-war decades when we believed (quite wrongly, as can now be plainly seen) that we were threatened by Asian communism, or China, or both. Today, they are in serious disarray whereas we are not."15

In a content analysis study of the Middie East news items in four "elite newspapers" and newscast of one television network in the United states, Mishra found coverage to be mostly concentrated in Istrael, Egjpt and iran. He attributed this focus of attention to the continuing Arab-Israeli conflict as well as the high stakes in the region for American economic, political, and military interests. 16

This survey correlating media coverage of foreign countries with national policy interests, suggests that newspaper accounts of foreign affairs are indeed colored by the philosophic, moral, and political perspectives prevailing in their own countries. Proximity was also seen to be a major cause of foreign news coverage, especially in the case of small to medium size powers that geographically abut a giant power.

Certainly this was the case in Australia during the 1960s. Southeast Asia was a factor in Australian foreign policy from the point-of-view of possible communist 13 J.C. Merrill, "The Image of the United States in Ten Mexican Dailies, Joumalism Ougrterly 56 ( Summer
1979): 377 14 J.A. Hart "The Flow of News between the United States and Canada," Ioumalism Ouarterly 40 (Summer 1963):

15 J.A.C. Mackie, "Australia and South-East Asia," Arenda for the Eishties, ed. Coral Bell (Canberra: Australian National University Press, 1980),124.

16 V.M. Mishra, "News from the Middle East in Five U.S. Media," Joumalism Ouarterly 56 (Summer 1979): 376. 
aggression from Indonesia or China. In the context of the Cold War and this official anxiety about China in the late 1950s and early 1960s, it was perhaps not surprising that Indonesia's actions vis-a-vis China and the Soviet Union would be looked on with such alarm by the Australian press and government alike. 


\section{CHAPTER 3}

\section{A Revier of Australian - Indonesian Relations}

According to the former Ambassador to Indonesia, F. Rawdon Dalrymple, Australia has always tried to hold to a friendly relationship with Indonesia. ${ }^{1}$ There were in fact good reasons for Australia's adherence to a restrained course of action. These included the inadequacies of Australia's defenses, the desire to avoid complications between West Irian and East New Guinea, and the growing seriousness of the war in Vietnam along with the possibility that Australia might become involved, as indeed she did from April, 1965.

Bruce Grant, a foreign correspondent for the Melboume Age throughout the 1960s said, "Indonesia has exerted on the minds of a strategically placed elite in Australia a fascination similar to that exercised on the British imagination by the Arab world in the first half of this century."2 Particularly during the 1960s, Australians were worried that Asians would someday sweep down from the north to fill their enormous empty spaces; the most likely candidate was Indonesia. With a population of 100 million (Australia's population in 1964 was 10 million), a high birth rate and crowded living space, Indonesia appeared volatile to Australian policymakers.

Indonesian culture grew from many small, almost self-sufficient coastal settlements, virtually inaccessible to each other overland but trading locally by sea. From the late thirteenth century onward, however, Indian trading settlements, founded first in northern Sumatra and later in Java, spread a growing Muslim culture throughout the

1 Personai corversation, April 9, 1989.

2 Bruce Grant, The Crises of Lovalty (Sydney: Angus \& Robertson, 1972), 83. 
islands. Christianity arrived with the Portuguese, who seized Malacca in 1511 but failed to establish permanent bases elsewhere. The Dutch who followed were more determined. In Maiacca, Batavia (now Jakarta), and many small coastal areas throughout the islands, their commercial and political interests expanded:

For over three centuries, the Dutch (except for a brief interruption by the French in the early 19th century) monopolized the spice trade in the area. During the 19th and 20th centuries their influence intensified and spread to other islands. Capital invested in a wide range of enterprises, from plantation cultivation to mining, developed Indonesia's resources on a large scale.

Freedom movements, developed during the 1920 s and 1930s, gained strength under Japanese occupation in World War 11; their leaders were ready to declare independence when the occupation force surrendered in 1945. After the Dutch returned, an armed struggle culminated in the Dutch withdrawing in 1949 from all but Irian Jaya, leaving the United States of Indonesia under its first President, Sukarno. Within a year, Sukarno unified the state, as a first step toward welding its disparate and widely-scattered elements. His subsequent policies as executive president earned the hostility of neigboring Malaya, took Indonesia out of the United Nations, alienated Australia, and brought the country to the verge of bankruptcy. According to Alan Renouf, Australia's secretary of the department of foreign affairs between 1973 and 1976, "Sukarno's militarism and Indonesia's faltering economy in combination with a burgeoning Communist party, placed a strain on the Australian government's diplomatic ingenuity. ${ }^{3}$

Indeed, Sukarno's policies of confrontation, first against the Dutch in West Irian and then against Malaya, a British Commonwealth state, had strained relations between

3 Alan Renouf, The Frightened Country (Adelaide: Griffin Press, Ltd., 1979), 103. 
Jakarta and Canberra to the point where Indonesian and Australian forces had confronted each other in the Strait of Malacca and in northern Borneo in 1964-65.4

Despite Australia's desire to establish an alliance with its nearest and most powerful neighbour, Indonesia's foreign policy, as orchestrated by Sukarno, was too antagonistic to her regional interests.

After the coup and counter-coup of September 1965, Sukarno was gradually eased from power as General Suharto slowly took control of all areas of government. As the months passed, Suharto began implementing policies more in accord with Australian interests, in particular the ending of Indonesia's confrontation of Malaysia. Since this was the only real source of contention between the two countries, the Australian government was eager to resume diplomatic ties. 5

4 Grant, 83.

5 Ibid, 92 


\section{CHAPTER 4}

\section{The Australian Government's Foreign Policy Toward Indonesia 1963-65}

Australia and Indonesia's security interests clashed between 1963 and 1965 over Sukarno's claim to West Irian and his "confrontation" of Australia's ally, Malaysia.

\section{The West Irian Conflict}

When Indonesia gained its independence from the Dutch in 1949, it did not, based on the terms of the Hague Agreement, gain possession of West New Guinea. The Dutch were to remain in West Irian (as it was renamed by Indonesia), for a year, at which point the final status of that territory was to be settled through negotiation. This decision was unacceptable to Sukarno who, from then on, demanded incorporation of the territory in Indonesia.

This was of some interest to Australia because West New Guinea adjoined the Australian territory of Papua and the United Nations trust territory of New Guinea (which Australia administered on behalf of the United Nations). As Angel pointed out, Australia feared that with Indonesia's militant anti-imperialist mood, there existed the danger that Jakarta, most likely with considerable United Nations backing, might be tempted to turn its anti-imperialist wrath against Australia as one of the last surviving colonial powers, especially once West Irian was liberated.1 After all, the types of reasons Australia

\footnotetext{
1 James Angel, Australia and Indonesia 1961-1970, eds. G. Greenwood \& N. Happer (Vancouver: University of
British Columbia Press, 1974), 365.
} 
advanced for the sluggishness of its decolonization were rather similar to those advanced by the Dutch in relation to Indonesia and later West Irian. Indeed, Burton said Australia's opposition to Indonesian claims to this territory was based more on a fear of nonEuropeans being close to Australian shores than on a belief in self-determination. ${ }^{2}$ Australia succeeded for some years in having the matter kept off the agenda of the United Nations General Assembley. Domestically, the coalition of the Liberal and Country parties made the retention of Dutch sovereignty one of its election policies. Albinski, in his book Australian Policies and.Attitudes Toward China, notes that at the climax of the 1963 election campaign, a Liberal Party political advertisement appeared in a national news magazine. It was headed, "Look to our perilous north before you vote." ${ }^{3}$ Albinski says that security inside Australia was seen as dependent on security on the outside, and the government's policies were directed toward that end. 4

Meanwhile, Sukarno broke diplomatic relations with the Netherlands and undertook a substantial military buildup, based mainly on Soviet aid since the U.S. sided with the Dutch and refused to sell Indonesia the needed equipment. According to Weinstein, Sukarno made clear by mid-1960 his determination not to stake Indonesia's claim to West Irian on hopes for "a gift from the imperialists. "5 The threat of armed conflict however worked. The United States finally abandoned its "pro-Dutch neutrality" and in August 1962 pressed the Dutch to settle the dispute on terms advantageous to Indonesia. 6

In the face of the United States' backdown, Australia reluctantly accepted arrangements under which control of West New Guinea would eventually be transferred to

2 J.W. Burton, Intermational Relations: A general theory (Cambridge, England: University Press, 1965), 142.

3 Henry S. Albinski, Australian Policies and Attitudes Tewand China (NewLesey, Pinowon Lhivesity Pes, 1965), 200.

4 Albinski, 203.

5 Franklin B. Weinstein, "Indonesian Foreign Policy and the Dilemma of Dependence, "Erom Sukarne to Soeherto (Ithace: Comell University Press, 1976), 165.

6 Weinstein, 166. 
an Indonesian administration.7 Australian public opinion was firmly opposed to Indonesia's acquisition of West New Guinea. The fear was that Indonesia's demonstrated predisposition to military force would pose a threat to the Australian territories just across the border from West New Guinea.

Australia in fact dropped its plans for a consul in West New Guinea when Indonesia insisted that it have reciprocal representation in Australian-ruled Papua-New Guinea. Suspicions of Indonesia's intentions were exacerbated by Sukarno's reluctance to define the border between West Irian and Papua-New Guinea. Not until Sukamo was ousted as President in September 1965 did Indonesia and Australia in 1966 finally agree on the 141st meridian for the border.

\section{Indonesia's "Confrontation" of Malaysia}

The concept of Malaysia, or the fusion under a single national standard of Malaya, Singapore, and the North Borneo, Sarawak and Brunei territories, was introduced by Malayan Prime Minister Tunku Abdul Rahman in mid-1961. Albinski notes that its motivation was to join Singapore to Malaya. "But the giant Chinese-origin population of Singapore required a counter-weight, hence the Borneo areas were included in the scheme."8

Although Brunei and Singapore chose not to join the federation, the remaining territories of Malaya, Borneo, Sarawak, and Sabah were formally constituted as Malaysia on September 16, 1963.

Indonesia declared that the new State was hostile to Indonesia's interests because it had British military bases. Indonesia also declared that North Borneo territories should not be part of Malaysia but should have the right to their own future. According to Renouf, the

7 Albinski, 202

8 Albinski, 198. 
Australian government suspected that Sukarno's objection to Borneo's incorporation into Malaysia was an attempt to dismember the Federation. If he succeeded asked Renouf, "where would Indonesia turn next?"9 Such fears of Indonesia's expansionist tendencies were a dominant influence among foreign policymakers in Australia during this period.

Sukarno saw the situation quite differently, although laced with an equivalent dose of paranoia: "We must oppose for our own sake the state of Malaysia as a tool of the Imperialist to encircle and halt Indonesia."10 But Australia found it hard to sympathize with Indonesia's official explanation of her hostility toward the Federation. Sukarno, Foreign Minister Subandrio, and Defense Minister General Nasution also argued that the large Chinese population in Malaysia could be an invitation to Communist China. "How can Malaysia, with its 10 million population, put up a blockage against Communist Chinese influence?" Subandrio asked. ${ }^{11}$

Indonesia broke off diplomatic relations with Malaysia and for three years, followed a policy of military aggression toward Malaysia which it called "Confrontation." Confrontation came short of an open declaration of war, instead employing techniques of propaganda, and guerilla raids, as well as playing upon the fears of international conflict entertained by Australia and the United States. In March, 1963, for example, Indonesian soldiers raided a police post in Sarawak, just across the border from Kalimantan (Indonesian Borneo). Australia was outraged at this aggression toward one of the Malaysian states and appealed in vain for the United States to intervene.

On March 11, 1964, Minister for External Affairs Garfield Barwick had pointed out that Indonesia, by interfering in the internal affairs of its neighbors, was breaching the United Nations Charter and the Afro-Asian Bandung Declaration, so meriting "international

\footnotetext{
9 Renouf, 422.

10 "Sukano Sees Malaysia as "Imperialist" Threat," Melboume Are 12 Dec. 1963: A4.

11 Speech by Subandrio on 20 Dec. 1963, in Sydney Moming Herald, 21 Dec. 1963: A1.
} 
disapprobation." 12 The Bandung Declaration came out of the first Afro-Asian conference that met in Bandung, Indonesia in April 1955. The main motivation of the conference was dissatisfaction with the domination of international politics by the quarrel between the American and Soviet blocs, and concern at the risk of war between the U.S. and China. The Bandung Declaration called for a world free from the interference of the big powers in the affairs of weaker nations. It also endorsed regional cooperation to ward off big.power intervention in Southeast Asia. ${ }^{13}$ According to Angel, the most important result of the conference was that it underlined the determination of the newly independent countries to guard their independence from encroachment from any outside source. ${ }^{14}$ While Sukarno argued that he was protecting Indonesia from Imperialist encirclement, his military aggression against the newly formed Federation of Malaysia represented for Australia a dangerous transgression of the conventions laid down by the conference.

More alarming still for Australian foreign policymakers, in April 1963, coinciding with the first Indonesia raid into Sarawak, Chinese Premier, Chairman Liu, paid his first visit to Indonesia. He declared that Indonesia and China were "comrades in arms," 15 while joining Sukarno in a joint communique endorsing independence for the three Borneo territories of Sarawak, Brunei, and Sabah, and affirming their determination to work together for the destruction of Malaysia. And on August 17, Sukarno proclaimed Indonesia a part of the "Jakarto-Phnom Penh-Hanoi-Peking-Pyongyang Axis." That same day, he declared Indonesia's intention to dedicate itself to "a year of living dangerously." Small groups of Indonesian paratroopers were dropped at several points in Malaysia. As confrontation intensified, Australia toughened her tone.

\footnotetext{
12 Renouf, 436.

13 Weinstein, 176.

14 Angel, 170.

15 Sutter, 1966: 5.
} 
On September 25, Sir Robert Menzies announced Australia's military support of Malaysia, with the forces stationed there in the Commonwealth Strategic Reserve.

One development associated with the West Irian and the Malaysian campaigns was the massive build-up in Indonesia's military, naval and air force capacity from1961.16 Eighty-five percent of the foreign aid received from the United States and Russia was used on military expenditures and aggression. This was the more serious because Australia's defense capabilities rapidly came to be seen as inadequate to match Indonesia's growing armed might. Fear of conflict with Indonesia was voiced by Arthur Calwell, the leader of the federal opposition. He said that information showed that the Indonesian air force was so strong it could destroy any Australian city, even if 24-hours notice were given for defense to be readied. 17

Nevertheless, to foreign policymakers in the Australian government, it was Sukarno's confrontation of Malaysia that was the more direct threat to Australia's own security. Concern was expressed in the Australian government publication, Australia in Facts and Figures:

Although Australia has sought to prowote friendship with Indonesia and to study Indonesia's point-of-view, Indonesia cannot expect that Australia can do other than condemn breaches of accepted international obligations and of accepted norms of international conduct. 18

For example, in a speech on April 9, 1964, Sukarno said, "Indonesia has 21 million volunteers ready to arm themselves with nuclear weapons to "overcome the increasing aggressiveness of the imperialists." 19 Surprisingly, but perhaps an indication .of his widely rumored irrationality during this time, he delivered this message to more than 150 delegates attending "The 11th World Congress against Atomic and Hydrogen Bombs."

16 T.B. Millar, Australie's Defence (Melbourme: Melboume University Press, 1965), 62.

17 "Calwell Blasts Australia's Defence System," Melbourne Are 28 Jan. 1963: A1.

18 Department of Foreign Affairs, Australin in Facts and Figures March Quarter, 1964: A7.

19 "Sukarno's Nuclear Threat," Melbonme Ares 28 July 1965: A4. 
In response to this threat, the Australian government under Menzies ordered from the United States the F-111 fighter planes. According to Albinski, in November of 1964, Subandrio warned that if Australia's recent defense buildup was designed to bully and subjugate Indonesia, Indonesia would have to reply to such a challenge. In January, 1965 Subandrio obtained Chinese credits worth at least $\$ 50$ million during his trip to Peking. "On both occasions," said Albinski, more pledges to crush Malaysia were exchanged."20 Also in January, Indonesia withdrew from the United Nations giving as her reason the fact that Malaysia had been allowed a seat on the Security Council. Even the Soviets opposed this Indonesian move; the Chinese were almost alone in praising it.

All this was received with consternation in Australia, coming as it did on the heels of the violent campaign to absorb West Irian. But the success of Malaysia was regarded as considerably more significant to Australia's security interests than the preservation of West New Guinea in Dutch hands had been. In fact, in January, 1962, Menzies had made it clear that a war over Dutch New Guinea "would solve no problems, but would create animosities from which nobody except the Communist Powers would profit."21

Australia's decision to resist by force, if necessary, Indonesia's confrontation of Malaysia can be attributed, says Renouf, to the perceived need to resist the spread of Communism. 22 Afterall, Indonesian success with confrontation could lead to a reverse domino theory from south to north with Singapore, a strategically placed island, being an early victim. Sukarno's Indonesia was under Communist influence, particularly Chinese Communist influence. Australia feared that if Indonesia succeeded in dismembering Malaysia, her regional security would be severely jeopardized. The Australian government's alarm at China's growing influence in Indonesia, is evident from a statement

20 uSukamo's Nuclear Threat," Melboume Age, 28 July 1965: A4.
21 "Menzies Against War Over Dutch New Guinea," Sydney Momine Herald, 13 Jan. 1962: 1.
22 Renouf, 176. 
in the March, 1965 issue of the Department of Foreign Affairs' Australia in Facts and Eiqunes:

A new element in the situation created by Indonesia's "Confrontation" of Malaysia has been created by some evidence of increasing contacts between the Indonesian and the Chinese Communists. 23

Indeed, Sutter says that "Concomitant with the Indonesian-Malaysian Confrontation and the standing feud between the P.K.I. and the Indonesian military, was Mainland China's support of the P.K.I.'s campaigns against both Malaysia and the Indonesian Army."24 For although Sukarno was President and Great Leader of the Revolution, he did not simply create a personal dictatorship. At least in theory, he shared control of guided democracy with the army leadership and the PKI. According to Angel, these three "guides" were linked in a delicately balanced relationship in which, until mid-1962, the army leadership appeared to be the more important and powerful of Sukamo's partners. Thereafter, says Angel, "Sukarno's partnership with the PKI became increasingly conspicuous....By the middle of 1965, there seemed to be no sizeable and effective political check on the PKI other than Sukarno, and he appeared to favor the drift to the left."25

Minister for External Affairs Barwick had said in May of 1963 that despite Australia's particular interest in the friendship of Indonesia, awareness of the Chinese threat would play a more and more important role in Australian-New Zealand thinking in the next 10 years. 26

Britain's withdrawal of troops east of Suez rendered the formation of a federation of Malaysian states of paramount importance to Australia. It was to be a buffer zone between Communist China and Australia's vulnerable northern shores. If Australia was

23 Australian Department of Foreign Affairs, Australia in Facts and Fivures, March Quarter, 1965: 12.

24 Sutter, 6.

25 Angel, 355.

26 "Threat of China Growing in Importance," Melboume Are, 30 May, 1963: A1. 
powerless to influence the rise of Communism in its nearest neighbor Indonesia, at least it could try to protect Malaysia, and thereby itself, from the Communist spectre.

Greenwood maintains that this commitment to support Malaysia against what was seen as Indonesian aggression, was firmer than in the case of Australian support of Dutch sovereignty in West Irian for a variety of reasons: The Commonwealth link, the alliance with Britain, the desire to show a willingness to shoulder responsibilities for regional security, the need to discourage any development of Indonesian expansionism, and the importance of ensuring the security of non-communist states. ${ }^{27}$

Thus, in a much more comprehensive way than in the West Irian dispute, the Malaysia issue brought Australia and Indonesia into opposition in a way that served to highlight the fundamental differences between Australian and Indonesian foreign policies.

The government's paranoia about Sukarno's ultimate intentions were voiced by a Liberal Party Minister for Parliament, Malcolm Fraser in April, 1965: "Indonesia plans to rule the Pacific. The Indonesian policy of Confrontation is part of an overall objective of Indonesia to expand and to dominate territories that are not her own." 28

Despite Australia's expressed disapproval of Confrontation, Greenwood said that there was at the same time "the frequently repeated qualification that Malaysia was the only issue on which Indonesia and Australia were opposed."29

This "dual policy," 30 as Greenwood describes it, set the stage for a resumption of cordial ties between the two countries if and when Indonesia abandoned Confrontation.

The decision by Prime Minister Menzies in September, 1963 to support in the maintenance of Malaysia's territorial integrity and political independence, was not taken hastily. Alan Watt, the director of the Australian Institute of International Affairs, said that

27 Greenwood, 103.

28 "Indonesia Plans to Rule the Pacific--Fraser." Melboume Age 15 April 1965: A7.

29 Greenwood, 109.

30 Ibid., 110. 
it followed a long period of diplomatic activity during which every effort was made by Barwick to maintain friendly relations with Indonesia and to induce Indonesia to seek an agreed and peaceful solution of its differences with the government of Malaysia.31 Only after the rejection by Sukarno of the report of the representative of the Secretary-General of the United Nations that "there is no doubt about the wishes of a sizeable majority of the peoples of these territories (Sabah and Sarawak) to join in the Federation of Malaysia,"32 and after the president had reiterated his intention to "crush" Malaysia, did the Australian government reluctantly conclude that these risks must be taken.

31 Alan Wath, Australian Foreign Policy 1938-65, (Boston: Cambridge University Press, 1967), 179.

32 Australim Department of External Affairs, Select Desuments on Malaysia (No. 1 of 1963): 201. 


\section{CHAPTER 5}

\section{The Tone of the Australian Press Toward Indonesia 1963 to 1965}

\section{Background}

Both the Melboume Age and the Sydney Moming Herald have become, over the past 150 years, two of the most respected metropolitan newspapers in Australia. The Age was started in 1854 by David and Ebenezer Syme who set out to lead public opinion, and inspired the first popular campaign to remove the property qualification which then restricted membership of the Victorian Legislative Assembly. The Syme family has continued to hold majority interest in the newspaper. The Sydney Herald was bought in 1841 by John Fairfax and Charles Kemp and renamed the Sydney Moming Herald in 1842. Kemp retired in 1853 and thereafter proprietorship has resided in the Fairfax family. ${ }^{1}$ In 1965 the Australian became Australia's first national newspaper. Over the next three years it gained sales equivalent to twenty to twenty-four percent of the combined sales of the Sydney Moming Herald and The Age (ren to twelve percent in each State).

The readership of the three newspapers was similar: educated, politically aware, white collar and professional. The other two moming newspapers, whose readership inclined to be less educated and less interested in national and world affairs, suffered little competition from the Australian. 2

1 Henry Mayer, The Press in Australis (Melboume: Lansdowne Press, 1968), xxi.

2 Mayer, xxii. 
In Sydney, the circulation of the Sydney Morning Herald in 1963 was 327,000 while that of the Daily Telegraph was 304,458. In Melbourne, the Melboume Age competed with the Sun News Pictorial with circulations in 1963 of 250,000 and 500,000 respectively. Both the Sydney Morning Herald and the The Age had higher metropolitan readerships than their morning competitors. In Melbourne, the metropolitan readership for The Age was 80 percent as compared to 60 percent for its competitor. In the Sydney, the metropolitan readership for the two morning papers was 75 percent for the Sydney Moming Herald and 63 percent for its competitor. ${ }^{3}$

The following will show the tone of these two elite newspapers to Indonesia during two crises periods before the ouster of President Sukarno.

\section{West Irian Conflict}

The newspapers' response to Sukarno's expansionist policies and military buildup, particularly during the West Irian dispute, was reflected in editorials during that period. An editorial in the Sydney Moming Herald, January 29, 1963 reprimanded the government for failing to resist Indonesian expansionism on Australia's own borders: "For such a failure, Australia may now be committed to supply military forces to resist Indonesian expansionism to Borneo."4

The Melbourne Age on February 22, 1963, pointed out that Australia's defense needs would have to be carefully reassessed in the face of the "increasing demands being made on us under our treaties with the Great Powers, and the belligerent and unpredictable attitude recently assumed by our closest neighbor, Indonesia." 5 When on May 1, 1963, Indonesia took over the administration of West Irian but not its sovereignty, an editorial in

3 W. Sprague Holden, Australia Goes to Press (Michigan: Wayne State University Press, 1961), 44.

4 "Confrontation' and What It May Mean," editorial, Sydney Momine Herald, 29 Jan. 1963: A2.

5 "Closer Look at Our Northern Problems," editorial, Melboume Age, 22 Feb. 1963: A2. 
the Melbourne Age stated, "The distinction, however, will be largely ignored both in Jakarta and in circles suspicious of Indonesia's intentions." 6 The press' suspicions of Indonesia's intentions reflected those of the Australian government. As already mentioned, the government feared that Sukarno's expansionist tendencies would pose a threat to the Australian territories just across the border from West New Guinea. Australia also declined to establish a Consul in West Irian when Indonesia insisted on having reciprocal representation in Australian-ruled Papua-New Guinea.

\section{Indonesia's "Confrontation" of Malaysia}

The Australian press, in concert with the Australian government, was firmly opposed to Indonesia's confrontation with Malaysia. An editorial on January 30, 1963 stated that although Indonesia's right to build a strong defense force for its own security is unchallenged, "in the case of Malaysia, which is the current cause of concern in Australia, Indonesia's definition of its rightful interests is perilously close to proving antagonistic."7

The Australian government's distrust of Indonesia's expansionist tendencies, was echoed in an editorial May 6, 1963:

Australia's interest in Indonesia's acceptance of Malaysia is self-evident.

We are closely associated with Malaya and support Malaysia as a solution to the withdrawal of British rule from the Borneo territories. We must be concerned to test the strength of Indonesia's position on the Borneo territories as an indication of what to expect on East New Guinea. 8

This sentiment was repeated in an editorial in the Sydney Moming Herald a few months later:

If Indonesia is to be kept out of the Communist camp and Communism kept from Australia's shores, the barrier

6 "Indonesia on Trust in W. Irian Take-over," editorial, Melboume Are, 1 May, 1963: A2.

7 "Indonesia's Right to Security," editorial, Melboume Age, 30 Jan. 1963: A2.

8 "Can Sukarno be Trusted?" editorial, Melboume Are 6 May, 1963: A2. 
against Chinese expansionism formed by Malaya, and soon by Malaysia, must be kept intact. There could be no more important contribution to Australia's security than this. 9

The Australian government's eventual, albeit reluctant, capitulation to Indonesia over the West Irian territory was roundly attacked in the Australian press:

It has not taken long for the Western Power's appeasement of Indonesia over West New Guinea to bear its inevitable fruit. President Sukamo has drawn the same conclusice as other dictators before him-that any price will be paid for peace, and that therefore territorial ambitions can be achieved by threat of war. ${ }^{10}$

The press also expressed concerns as to Sukarno's expansionism if Malaysia was dismembered by a strongly Communist Indonesia. They therefore applauded America's blunt warning to Sukamo that Washington would oppose any aggressive Indonesian action towards Malaysia, not least because such aggression would involve Britain and Australia, both allies of the United States. This waming "strikes a blow for stability in Southeast Asia on which the containment of Communism depends." 11

Despite the position the press took toward Sukarno, it shared the Australian government's belief that harmony between the two nations should be established when the opportunity presented itself. In the Sydney Moming Herald in June, 1963, an editorial noted that although Indonesia "is militarily dependent on Russia and her Communist Party is the largest in the world outside of Russia and China...This does not preclude--given a change of heart in Jakarta-friendly relations and economic cooperation with her neighbors." 12 Only a month earlier, Barwick had said that awareness of the Chinese gave Australia a particular interest in the friendship of Indonesia.

In September, 1963, however, Indonesia broke off diplomatic relations with Malaysia. Any thoughts of future friendly ties being established between Australia and

9 "Malaysia's Security is Ours," editorial, Sydney Momine Herald. 22 July, 1963: A2.

10 "The Price of Appeasement," editorial, Sydney Moming Herald, 13 Feb. 1963: A2.

11 "An American "Word" with Dr. Sukamo," editorial, Sydney Momine Herald, 16 Jan. 1964: A2.

12 "Future Accord with Indonesia?" editorial, Sydney Momine Herald, 20 June 1964: A 2. 
Indonesia were, at least for the moment, set aside. An editorial in the Melbourne Age advised that "Australians would be foolish to minimize the gravity of the situation which has developedi in tne near-North in the past week. What course Indonesia will take in its present angry mood is impossible to foretell."13 This statement clearly reflected the attitude of the Australian government (the Liberal-Country Party), whose election slogan was "Look to our perilous north before you vote."

Like the government, the Australian press did not trust Indonesia's sincerity in agreeing to new peace talks on Malaysia. In January 1964, a front-page headline in the Sydney Moming Herald voiced this distrust: "Outburst by Sukarno seen as danger to Peace Bid." Sukarno was quoted as saying, "Indonesia may change its tactics but our goal will remain the same." 14 Indeed, just two months later, a front-page headline in the Melboume Age quoted President Sukarno as saying Indonesia had 21 million volunteers ready "to destroy Malaysia." 15 An editorial in September 1964 demonstrated the press's support of the Australian Government's position: "Indonesian airborne assault on Malaysia was a cynical act of aggression inspired and directed by a dictator obsessed with the idea of conquest....Australia is fully pledged to the defense of Malaysia and must be not only willing but ready to meet its obligations." 16

By March 1965, Australian troops were stationed in Borneo and Australia's name began appearing in the list of Indonesia's "neo-colonialist" enemies. The MelbourneAge said that "with Australian troops now operating in Borneo and the prospect of an increasing number of armed clashes with the Indonesian forces, Australia's relations with Indonesia may now also be reaching a crisis point." 17

\footnotetext{
13 "Crisis to the North," editorial, Melboume Aqe. 25 Sept. 1963: A2.

14 "Outburst by Sukamo Seen As Danger to Peace Bid," Sydney Moming Herald. 25 Jan. 1964: A1.

15 "21 Million Volunteers Ready to Destroy Malaysia," Melboume Are 10 April 1964: Al.

16 "Aggression against Malaysia," editorial, Melboume Ags 4 Sept. 1964: A2.

17 "Australia on Indonesia's List of "neo-colonialist" Enemies," Melboume Are, 29 March 1965: 5.
} 
The failure of Indonesia to negotiate a border between West Irian and East New Guinea continued to rankle the Australian government. An editorial in the Sydney Morming Herald in June 1965, gave voice to this concern and to suspicions of Sukarno's intentions:

When Canberra and Jakarta agreed to mark a border between West Irian and East New Guinea, Indonesia was still in the United Nations and Sukamo hadn't delivered his speech predicting explosion and rebellion in Oceania and the Pacific. Neither event provides grounds for believing that Indonesia has ambitions over Australian territory, but even the best of friends usually like to put a fence along the property line. 18

When seven prominent right-wing and moderate leaders were purged from the PNI in August 1965 at Sukarno's request, the Sydney Morning Herald expressed alarm: "This places the party's central organization completely in the hands of the Left-wing and proCommunist faction."19 Indeed, just nine days later, Creighton Burns, in Indonesia reporting on Sukarno's Independence Day speech, said, "Diplomatic sources believe that the bias in the President's speech toward anti-imperialism rather than Confrontation reflects China's growing diplomatic influence in Jakarta."20

18 "A Common Border," editorial, Sydney Momine Herald, 22 June 1965: A2.

19 A.A.P. Reuter. "Indonesia Moves Closer to the Left," Sydney Momine Herald 9 August 1965: A3. 20 Creighton Burms. "Independence Day Speech the Mildest National Day Speech in Years," Melboume Are 18
August 1965: A2. 


\section{CHAPTER 6}

\section{The Australian Government's Foreign_Policy Toward Indonesia 1965 to 1970}

On the night of September 30, 1965, an event occurred that completely changed the course of Indonesian affairs. What started out as an attempt by the PKI to gain control in Indonesia by killing the most powerful army generals, resulted in the generals, lead by Suharto, taking control within hours and suppressing the insurrection. It is unclear if President Sukamo were involved in the attempted coup, but as the months passed, confidence in his leadership ebbed as Suharto took control of the reins of power. By the end of 1967, Sukarno had resigned and Suharto had became the new President.

According to former Australian Secretary of Foreign Affairs, Renouf, when the coup and counter-coup occurred in Indonesia, Australia's comment was appropriately restrained. ${ }^{1}$ Hasluck, the new minister of external affairs as of April 24, 1964 said the situation was so "fluid" that "it would be neither prudent nor helpful...to engage in comment or speculation about it." 2 This wait-and-see attitude gradually gave way over the succeeding months, to an active role in international efforts to settle Indonesia's economic problems.

In June, 1966 at peace talks held in Bangkok, Malaysian, and Indonesian leaders brought Confrontation to an end. Although Australia was always poised to resume diplomatic relations with Indonesia, the persistence of Indonesia's military aggression

1 Renouf, 325.

2 Commonwealth Parliamentary Debates, 8 March, 1966: 27. 
toward Australia's ally Malaysia, made goodwill impossible. On August 12, 1966 hostilities between Malaysia and Indonesia were officially ended. Australian Prime Minister Holt said his government was delighted the agreement was concluded. ${ }^{3}$

Although Sukarno remained President and although the army leadership initially pledged its loyalty to him and to the Indonesian Revolution, he came under increasing public criticism for the economic situation produced by his policies, for his past and present championing of the communists and for his possible involvement in the coup. Over the succeeding months, he was steadily deprived of power and his closest supporters were eased out as General Suharto, the new commander of the army, set about creating his New Order. By mid-1967, the New Order had clearly replaced the old order and had brought to a dramatic end the drift to the left that had characterized the Indonesian political scene under guided democracy. Not only was the New Order non-Communist, it was, according to Angel, "forcefully anti-Communist."4 On November 1, 1967, Indonesian diplomats were brought home from Beijing and all remaining Chinese Embassy staff were evacuated from Jakarta.

Old order priorities were reversed says Angel:

Domestic considerations were given priority over foreign ventures, economic needs were accorded greater importance than political and ideological considerations; consolidation and rehabilitation replaced the Revolution as the dominant concern of the government. The Revolution was over. 5

While West Irian had been a complete victory, although at great cost to the economy, the anti-Malaysia campaign, because of the soft-pedalling of the high command and the more vigorous opposition of Britain, Australia, and to some extent also, the United States, ran into a military-diplomatic stalemate which, as Pender said, "completed the final

3 "Indonesia and Malaysia End Hostilities," Sydney Momine Herald, 12 August 1966: 1. 
disintegration of the Indonesian economy and pushed the country into financial bankruptcy of gigantic proportions."6

One of Suharto's first moves was to cut off all defense spending and give absolute priority to the rebuilding of Indonesia's economy.

Furthermore, after years of empty promises from Sukarno to establish a border between West Irian and the Australian territory of New Guinea, this was finally accomplished in July, 1966.

These post-coup developments led to corresponding changes in Australia's foreign policy toward Indonesia.

4 Angel, 380.

5 Ibid., 382.

6 C.L.M. Penders. The Life and Times of Sukarno (Rutherford, New Jersey: Fairleigh Dickinson University Press, 1974), 178. 


\section{CHAPTER 7}

\section{How The Australian Government Manifested Its Change in Foreign Policy Toward Indonesia}

After the ouster of Sukamo, the Australian government manifested its change in foreign policy toward Indonesia in a way that dramatically contrasted with its treatment of that country prior to 1966.

\section{a) Foreign Aid}

At the height of Indonesia's confrontation with Malaysia, Australian foreign aid was merely a trickle. When the abortive coup of October, 1 1) Sukarno era, Australia had spent some $\$ 13$ million in capital and in technical assistance to Indonesia over 12 years. According to H.W. Arndt in his book, Australian Economic Aid to Indonesia, the Australian goverment, supported by the great majority of the Australian public, made no secret of "its relief and delight at the turn of events in Indonesia which followed the October, 1965 coup attempt."1 For example, in the March quarter, 1969 Australia in Facts and Figures, Prime Minister John Gorton informed the House of Representatives that aid to Indonesia was being increased. ${ }^{2}$ This aid would continue a program of the same kind as had been established in 1967. This decision emphasized the importance that the government attached to helping Indonesia achieve adequate economic growth now that under President Suharto, its political and diplomatic goals were more in

1 H.W. Amdh, Ausmalian Economic.Aid to Indonesia (Canberra: Australian National University Press, 1970), 176.

2 Australia in Facts and Figures, March Quarter, 1969:12. 
accord with those of Australia's. By 1970, Indonesia was the largest recipient of Australian foreign aid ${ }^{3}$

\section{b) Cultural and economic exchanges}

On August 3, 1967, senior executives from 50 Australian companies and banks left Sydney to attend the Pacific Indonesian Business Association Conference. The subject of discussion was Indonesian economic problems. On June 15, 1968, Indonesia and Australia signed a cultural agreement under which they would promote press, radio and television co-operation and the teaching of erch other's language in their educational institutions. They agreed to exchange research workers, scholars and students to develop scientific knowledge and technical skill in their countries.

c) Military Assistance

The high degree of trust and friendship the government now attempted to foster between itself and Indonesia was demonstrated by a bilateral military accord providing for Australian military assistance in several areas, including the training of Indonesian military personnel in Australia and an agreement to hold joint military exercises. In November 1967, for example, some Indonesian servicemen made a study tour of Australian air force bases.

\section{d) Statements by Govemment Officials}

That Suharto moved rapidly to resolve one of Australia's main points of contention with Indonesia, Confrontation with Malaysia, was welcome news to Australian foreign affairs interests. Prime Minister Holt was quoted in the Sydney Moming Herald on the

3 Arndt, 1970, 65. 
day Indonesia and Malaysia formerly ended hostilities as saying that his government was "delighted" the agreement was concluded. 4

On March 4, 1968 when Australia more than doubled its aid to Indonesia, minister for external affairs, Hasluck, said the government's decision was "evidence of the importance Australia placed on assisting its closest neighbor to achieve once again a state of economic strength." He added that during the past two years, Australia had watched with keen interest the "courageous attempts made by General Suharto and his Ministers to grapple with the immense economic problems that confronted them when they assumed power in 1965. 15

Prime Minister Gorton said of his Asian visit in June 1968 that in Indonesia, "I had lengthy discussions with President Suharto which I think will further friendship, cooperation and understanding between our countries." 6 Indeed, in 1972, the then Minister for Foreign Affairs, Nigel Bowen, was able to say, "It will be our aim to maintain the steady development of the close relationship we now enjoy with Indonesia."7

\footnotetext{
4 "Australia Welcomes End to Confrontation" Sytney Maning Herald 12 Aug. 1966: A1.

5 "More Aid for Indonesia," Sydney Morning Herold 4 March 1968: A3.

6 "Diplomatic Channels between Australia and Indonesia Opening Up," MelboumedAge 18 June 1968: A3.

7 The quotation is from Claire Clarke, ed. Australien Foreion Policy (Victoria: The Dominion Press, i9̂73), 184.
} 


\section{Chapter 8}

\section{The Tone of the Australian Press Toward Indonesia 1965 to 1970}

Like the Australian government, the press also had a wait-and-see attitude to Indonesia after Sukarno's ouster. Not until July 1966 did an editorial appear in the Melboume Age that indicated that it too, was undergoing a change in tone:

Indonesia continues to give a copybook performance of a country seeking to regain international respectability. For Australia, it is significant that three main aspects of this performance--the winding down of Confrontation, the marking of the New Guinea border and Jakarta's new approach to its suzerainty in West Irian--give direct promise of fairly comfortable relations between ourselves and Indonesia. 1

In August 1966, a story on the front page of the Melboume Age reporting on Hasluck's proposed visit to Jakarta said: "Mr. Hasluck's visit would enhance the already close relations between the two countries." 2

An editorial in the Sydney Morning Herald four days later lauded the Australian government's prevailing foreign policy toward Indonesia:

One of the most important interests of Australia's foreign policy is that her great Asian neighbor Indonesia should be stable, prosperous and under the control of a friendly government. The imminent end to Confrontation--it seems likely to come this week--is an added reason for Ministers' visit this week. This will open the door to resumption of normal relations between Indonesia and Australia. 3

\footnotetext{
1 "Incionesia's Copy Book Performance," editorial, Sydney Morming Herald, 4 July 1966: A2.

2 "Indonesian's Expect Visit by Holt," Melboume Are 4 Aug. 1966: Al.

3 "Indonesia's Security is Our's," editorial, Sydney Moming Herald, 8 Aug. 1966: A2.
} 
Both the Syaney Moming Herald and the Melboume Age strongly reflected the government's change in foreign policy toward Indonesia because they shared with the government the belief that diplomatic harmony with Indonesia would ensure Australia's national security in the region. On August 12,1966, an editorial in the Sydney Moming Herald headed, "Fresh Start," strongly endorsed the government's new position on Indonesia:

No country will welcome the end of the undeclared war between Indonesia and Malaysia with more heartfelt relief than Australia. "Confrontation" threatened Australia's whole future by embroiling her with her nearest and most powerful Asian neighbor, it opened up for her the prospect of having a Communist power closely allied with Peking on her border. ${ }^{4}$

The press deemed the Australian government's decision to double Australia's aid to Indonesia as being "wise and welcome--and it may be added, long overdue."5 Editorials in both the Melboume Age and the Sydney Moming Herald during this period urged the government to give Indonesia substantial foreign aid to avoid a reversion to the chaos of the last days of the Sukarno regime. Indonesia under Sukarno had been a country focussed primarily on external affairs while its internal problems were largely ignored. Suharto reversed this focus, thereby fostering a cautious optimism in the Australian government and press alike. An editorial in the Melboume Age in March, 1968 clearly demonstrates how closely the press reflected the government's new attitude toward Indonesia:

With the skill of a trained mountaineer, General Suharto has ascended to the rank of President of Indonesia. The climb was not easy, and a single false foothold could have been disastrous. Now that he has reached the summit, the General has a period of five years to demonstrate that his policies of economic rehabilitation and co-operation with friendly powers can produce real and visible benefits for his 112 million people. 6

\footnotetext{
4 "Fresh Start," edicorial, Sydney Moming Hersld, 12 Aug. 1966: A2.

5 "Financial Aid to Indonesis," editorial, Melbovime.Are 5 March 1968: A2.

6 "No New Dictator," editorial, Melboume Are, 29 March 1968: A5.
} 
The press was right behind the Australian government giving encouragement to lend a hand in the repair. An editorial in October, 1968 stated:

As a member of the Indonesia Club, we will be called upon to make a further substantial increase if we are to play a real part in maintaining the economic stability on which General Suharto's government rests...The price of one F-111 bomber (with spares and service)is not very much to contribute to our nearest most populous and influential neighbor. In Australian terms, aid for Indonesia is more than benevolence; it is enlightened self-interest."7

In 1962 when Joumalist Neil Jillet visited Indonesia he wrote, "Guided democracy was working up to its maddest, self-annihilating excesses. Everywhere the cry was to free Irian Barat, and crush Malaysia." When he returned in 1969, the frenetic desire for regional domination had given way to the search for regional co-operation. "Tread warily," he said, has replaced Sukarno's "live dangerously as the national motto."8

In 1964 when Sukarno entered into arms negotiations with the Soviet Union, the Australian response was one of alarm. The leader of the Opposition, Arthur Calwell had called into question Australia's ability to defend.itself against an increasingly militant Indonesia, and Menzies, Australia's Prime Minister, ordered a fleet of F-111 fighter jets from the United States. In 1969, however, when Suharto entered into similar negotiations with the Soviets, the Australian response was quite different:

Since the Indonesian Armed Forces have buen trained to use Russian equipment, and, in many cases, could get by simply with more spare parts, the cheapest and easiest way for Indonesia would be to enter into new arrangements with the Soviet Union.

Nowhere in the world has the Soviet Union received less in return for its investment than it has in Indonesia. ${ }^{9}$

7 "Our Aid for Asia," editorial, Melboume Age 11 Oct. 1968: A5.

8 Neil Jillet, "Change in Indonesia since Sukano," Melboume Age, 29 Jan. 1969: A5.

9 Denis Wamer, "Indonesia Looks at Soviet Links," Sydiney Momine Herald, 27 Aug. 1969: A3. 
Indeed, the press strongly supported Suharto's apparent efforts in the following months to eradicate the political, economic and diplomatic harm inflicted on Indonesia by Sukarno. In March 1970 for example, the Melbourne Age reported approvingly of a visit Suharto made to Kuala Lumpar for a three-day goodwill visit to Malaysia-the first by an Indonesian head-of-state since the Federation was born:

Mr. Malik and the Malaysian Deputy Prime Minister (Tun Abdul Razak) are expected to sign a renewed friendship treaty--once marred by deposed President Sukarno's armed confrontation against Malaysia in 1965 . The visit is also intended to demonstrate that the confrontation has been completely abandoned. 10

10 “Suharto On Goodwill Visit to Malaysia," Melboume Are, 16 March 1970: A4. 


\section{CHAPTER 9}

\section{Conclusion}

Although the Australian press was in no way controlled by its government as in Taiwan or the Soviet Union, still, it closely reflected the government's change in foreign policy toward Indonesia after the ouster of Sukarno.

This study has given two major reasons for the concordance between press and government: both subscribed to the Domino Theory and both saw Sukarno, and his efforts to dismember the Federation of Malaysia, as a threat to Australia's regional security. The government, however, was slower to respond to Sukarno because of the need to work through diplomatic channels.

Researchers have found that mass media ethnocentrism is pervasive throughout the international press. The Australian press was no exception. H.C. Mott, the former senior spokesman for Australia's Department of Foreign Affairs has noted that the Australian press often seems to regard developing countries from a strictly Australian perspective. ${ }^{1}$ Australia is a very isolated country, not just geographically, but also culturally and ethnically. Awareness of its uniqueness within a predominantly Asian region fostered, particularly during the Sukarno era, a "garrison mentality" in both the government and in the press. Although the purpose of SEATO (South-East Asia Treaty Organization), created at Manila on September 8. 1954 by Australia, Britain, France, New Zealand, Pakistan, the Philippines, Thailand, and the United States, was to provide a defensive alliance for the

1 H.C Mott, "The Media and Foreign Policy," Australia Foreion Affairs Record (Department of Foreign Affairs, Australian Government Publishing Service, N.S.W., Australia), Vol. 46, 10 Oct. 1976: 545-550. 
protection, in part, of Australia's regional security, it lacked the long-term commitment of members' forces that was a feature of Nato.

Consequently, when Australia's security, from the threat of communism, was jeopardized by Sukarno's foreign policies, both the Australian government and the press condemned Indonesia and supported the newly forming, and democratic, Federation of Malaysia.

Indeed, by 1963, it became apparent that political differences between Indonesia and Australia were abundant. Indonesia, under Sukarno, saw its regional security as completely at variance with Australia's. Where Australia saw the formation of Malaysia as a buffer zone between it and "monolithic" communism, Indonesia saw the Federation as part of an "Imperialist" plot to encircle and destroy Indonesia. Similarly, where Australia perceived Communist China as a threat to its security, Indonesia saw China as an ally in its fight against the formation of Malaysia. With such a clash in foreign policy interests, conflict between the two countries was scarcely surprising. In addition, Indonesia possessed the largest communist party outside of China and the Soviet Union and Sukamo made no secret of his alliances with these countries. Stability, prosperity, territorial integrity and effective government were sought by Indonesia, but under Sukarno these were subsidiary to broader revolutionary objectives. And finally, there was conflict over British and American involvement in Southeast Asia. Understandable, since Indonesia did not share Australia's fear of communist expansion.

Australia's fear of Indonesia's susceptibility to communism is analagous to the United States' response to Cuba in the early 1960 s when it was feared that Soviet bases were being established there. Cuba's geographical proximity to the United States rendered a Soviet presence ominous. The cold war "mentality" precluded the possibility of negotiation between the United States and Cuba as it did between Australia and Indonesia. 
In Australia's case, however, democratic Malaysia was to be the ally Indonesia had failed to be. In the formation of the Federation of Malaysian states lay Australia's hopes for a buffer zone against the spread of communism. When Indonesia began its confrontation of Malaysia, both the Australian government and the Australian press expressed outrage.

Studies of other Western newspapers have found that their coverage of a foreign country tends to parallel the foreign policy of their governments toward that country. When there is disharmony with a country, the news coverage tends to be unfavorable, and when a drastic change occurs in the relationship with the country, its news coverage changes accordingly. But foreign policy and editorial content concur only if the press agrees with its government's policies.

During the Vietnam war, for example, the U.S press widely opposed the government's presence in Southeast Asia. Again during the Grenada incident, the United States press failed to reflect government foreign policy because it did not agree that the United States was either threatened by, or vulnerable to, Grenada.

This was not the case, however, in Australia. Between 1963 and October 1965, the Australian press, as demonstrated in its editorials, shared the government's belief that Indonesia's stance against Malaysia, and Sukarno's alliance with Communist China, put Australia's regional security in immediate jeopardy. Not only was Indonesia openly sympathetic to the communists, but she was trying to weaken Australia's only other possible ally in the region. Since negotiation with Sukamo was deemed impossible, the press and the govemment concurred that Malaysia must be protected against Indonesian military incursions.

Although the Sydney Moming Herald and the Melboume Age were liberal newspapers, they were certainly not left-wing publications, their political and cultural values firmly embedded in the Western, democratic tradition. It was not surprising 
therefore that they supported the government's foreign policy toward Indonesia since any other position would have been anathema to Australia's interests and national security.

Within nine months of Sukarno's ouster, Suharto, the new President, began implementing policies that dramatically changed Australia's perception of Indonesia. This situation is analagous to the changing relations between the United States and the Soviet Union since Mikhail Gorbachev assumed power in Russia. His policies of perestroika and glasnost, as well as the negotiations between the two powers to reduce armaments in Europe, have all contributed to a drarnatic winding down of the Cold War. As United States foreign policy toward the Soviet Union has become more friendly and open, so too has the tone of the United States press. Similarly in Australia, with the winding down of Indonesia's confrontation of Malaysia, eradication of the PKI, and the marking of the New Guinea bonder, relations between Indonesia and Australia went from hostile and distrustful to harmonious and supportive. Accordingly, the Australian press, sharing the government's belief in the desirability of cordial relations with Indonesia, followed suit. 


\section{BIBLIOGRAPHY}

\section{Books and Journals}

Albinski, Henry S. Australian Policies and Attitudes toward China. Princeton: Princeton University Press, 1965.

Angel, James. "Australia and Indonesia, 1961-1970," in Australia in World Affairs 19661970, eds. Gordon Greenwood and Norman Harper. Vancouver: University of British Columbia Press, 1974.

Arndt, H.W. Australian Economic Aid to Indonesia Canberra: Australian National University Press, 1970.

Berelson, Bernard. Content Analysis in Communication Research. New York: Hafner Publishing Co., 1971.

Budd, R.W. "U.S. News in the Press Down Under," Public Opinion Ouarterly,28, 1: 39$54,1964$.

Budd, R.W., R.K. Thorpe, and L. Donohew. Content Analysis ofCommunications. New York: The Macmillan Co., 1967.

Burton, J.W. Intemational Relations: A General Theory. Cambridge England: University Press, 1965.

Bush, Chilton. "A System of Categories for General News Content," Journalism Ouarterly, Volume 37, Summer, 1960.

Clark, Claire, ed. Australian Foreign Policy. Victoria: Dominion Press, 1973.

Cohen, B.C. The Press and Foreign Policy. New Jersey: Princeton University Press, 1963.

Dorman, W.A. and M. Farhang. The U.S. Press and Irani ForeignPolicy and the Journalism of Deference. Berkeley: University of California Press, 1987.

Frost, Frank. Australia's War in Vietnam. Sydney: Allen and Unwin, 1987.

Gans, H.J. Deciding What's News. New York: Vintage Books, 1979.

Grant, Bruce. The Crises of Loyalty. Sydney: Angus and Robertson, 1972.

Greenwood, G. and N. Harper, eds. Austalia in Worid Âिairsi96i-65. Vancouver: University of British Columbia Press, 1974. 
Hart, J.A. "The Flow of News between the United States and Canada," Journelism Quarterly, 40: 70-74, 1963.

Hastings, Peter. "Near Northern and Pacific Neighbors," in Agenda for the Eighties, ed. Coral Bell. Canberra: Australian National University Press, Chapter 8, 163, 1980.

Kriesberg, M. "Soviet News in the New York Times," Public Opinion Quarterly, 10: 540$564,1946-47$.

Liu, H.C. and Gunaratne, S.A. "Foreign News in Two Asian Dailies," Gazette, 18, 1: 3741, 1972.

Lynch, M.D. and Ef̂िenäi, Â. "The Editorial Treatment of India in the New York Times," Journalism Quarterly, 41: 430-432, 1964.

Mackie, J.A.C. "Australia and South-east Asia," in Agenda for the Eighties, ed. Coral Bell. Canberra: Australian National University Press, 1980: 123-127.

Merrill, J.C. "The Image of the United States in Ten Mexican Dailies," Joumalism Quarterly, 56: 373-378, 1962.

Millar, T.B. Australia's Defence. Melbourne: Melbourne University Press, 1965.

Mintz, Jeanne S. Indonesia: A Profile. New Jersey: D. Van Nostrand Company, Inc., 1961.

Mishra, V.M. "News from the Middle East in Five U.S. Media," Joumalism Quarterly, 56: 374-378, 1979.

Mott, H.C. "The Media and Foreign Policy," Australian Foreign Affairs Record, Department of Foreign Affairs, Australian Government Publishing Service, N.S.W. Australia, Vol. 46, 10, Oct., 545-550, 1976.

Penders, C.L.M. The Life and Times of Sukarne. Rutherford, New Jersey: Fairleigh Dickinson University Press, 1974.

Renouf, Alan. The Erightened Country. Adelaide: Griffin Press, Ltd., 1979.

Sahin, H. "Turkish Politics in the New York Times." Joumalism Ouarterly, 50: 685-689, 1973.

Schlegel, J.P. "Patterns of Diplomacy: Canada and Australia in the Third World," The Australian Joumal of Politics and History, Vol. 30, No.1, 1984.

Stempel, G.H. "Sample Size of Classifying Subject Matter in Dailies." \ournalism Quarterly, 29: 333-334, 1984.

Street, Tony. Speech to National Press Club in Canberra as reported in the Australian Foreign Affairs Record, Department of Foreign Affairs, Australian Government Publishing Service, N.S.W, Vol. 52, 2, Feb., 123-127, 1981. 
Watt, Alan. Australian Foreign Policy 1938-1965. New Jersey: Cambridge University Press, 1967.

Weinstein, F.R. Indonesian Foreign Policy and the Dilemma ofDependence: From Sukarno to Suharto. New York: Cornell University Press, 1976.

\section{Nerrspapers}

"Sukamo Sees Malaysia as "Imperialist" Threat." Melboume Age, 12 Dec. 1963, col. 2-4. Speech by Subandrio on 20 Dec. 1S63, in Sydney Morninghterald, 21 Dec. 1963: 1.

“Calwell Blasts Australia's Defence System." Melbourne Age, 28 Jan. 1963: 1.

“Sukarno's Nuclear Threat," Melbourne Age, 28 July 1965: 4.

"Threat of China Growing in Importance." Meiboume Age, 30 May 1963: 1.

"Menzies Against War Over Dutch New Guinea." Sydney Morning Herald, 13 Jan. 1962: 1 .

"Indonesia Plans to Rule the Pacific--Fraser." Melbourne Age, 15 April, 1965: 7.

"'Confrontation" and What It May Mean," editorial. Sydney Moming Herald, 29 Jan. 1963: 2.

"Closer Look at Our Northern Problems," editorial. Melbourne Age, 22 Feb.1963: 2.

"Indonesia on Trust in W. Irian Take-over," editorial. Melboume Age, 1 May 1963: 2.

"Indonesia's Right to Security," editorial. Melboume Age, 30 Jan. 1963: 2.

"Can Sukarno be Trusted?" editorial. Melboume Age, 6 May, 1963: 2

"Malaysia's Security is Ours," editorial. Sydney Moming Herald, 22 July 1963: 2.

"The Price of Appeasement," editorial. Sydney Moming Herald, 13 Feb. 1963: 2.

. "An American "Word" with Dr. Sukarno," editorial. Sydney Moming Herald, 16 Jan. 1964: 2.

"Future Accord with Indonesia?" editorial. Sydney Morning Herald, 20 June 1964: 2.

"Crisis to the North," editorial. Melbourne Age, 25 Sept. 1963: 2.

"Outburst by Sukarno Seen as Danger to Peace Bid." Sydney Moming Herald, 25 Jan. 1964: 1 . 
"21 million Volunteers Ready to Destroy Malaysia." Melbourne Age, 10 April 1964: 1.

"Aggression against Malaysia," editorial. Melboume Age, 4 Sept. 1964: 2.

"Australia on Indonesia's List of "neo-colonialist" Enemies." Melboume Age, 29 March 1965: col. 2-5.

"A Common Border," editorial. Sydney Morning Herald, 22 June 1965: 2 A.A.P. Reuter. "Indonesia Moves Closer to the Left." SvdneyMMorning Herald, 9 Aug.
1965: col. 3-3.

Creighton Burns. "Independence Day Speech the Mildest National Day Speech in Years." Melbourne Age, 18 Aug. 1965: 2.

"Indonesia and Malaysia End Hostilities." Sydney Moming Herald, 12 Aug. 1966: 1.

"Australia Welcomes End to Confrontation." Sydney Morning Herald, 12 Aug. 1966: 1.

"More Aid for Indonesia." Sydney Moming Herald, 4 March 1968: 3.

"Diplomatic Channels between Australia and Indonesia Opening Up." Melboume Age, 18
June 1968: 3

"Indonesia's Copy Book Performance," editorial. Sydney Moming Herald, 4 July 1966: 2

"Indonesian's Expect Visit by Holt." Melboume Age, 4 Aug. 1966: 1.

"Indonesia's Security is Our's," editorial. Sydney Moming Herald, 8 Aug. 1966: 2

"Fresh Starit," editorial. Sydney Moming Herald, 12 Aug. 1966: 2.

"Financial Aid to Indonesia," editorial. Melboume Age, 5 March 1968: 2.

"No New Dictator," editorial. Melboume Age, 29 March 1968: 5

"Our Aid for Asia," editorial. Melboume Age, 11 Oct. 1968: 5.

Neil Jillet, "Change in Indonesia since Sukarno." Melbourne.Age, 29 Jan. 1969: 5. Denis Warner, "Indonesia Looks at Soviet Links." Sydney Morning Herald, 27 Aug.
1969: col. 3-3.

"Suharto on Goodwill Visit to Malaysia." Melboume Age, 16 March 1970: col. 3-4. 


\section{Government_Publications}

Department of Foreign Affairs. Australia in Facts and Figures, March Quarter, 1964, p.p. 1-79.

Âustralian Department of External Affairs. Select Documents on Malavsia (No. 1 of 1963), p.p. 1-24.

Commonweath Parliamentary Débates, 8 March 196́: 27.

Department of Foreign Affairs. Australia in Facts and Figures, March Quarter, 1965, p.p. 1-66.

Department of Foreign Affairs. Alsstralia in Facts and Figures, March Quarter, 1969, p.p.1-72. 